ISSN 2080-1653

DOI 10.24917/20801653.332.5

\title{
KRZYSZTOF GWOSDZ
}

Uniwersytet Jagielloński, Kraków, Polska

Jagiellonian University, Krakow, Poland

\section{GRZEGORZ MicEK}

Uniwersytet Jagielloński, Kraków, Polska

Jagiellonian University, Krakow, Poland

\section{AgNieszKa SobALA-GWOSDZ}

Państwowa Wyższa Szkoła Techniczno-Ekonomiczna w Jarosławiu, Polska

The Bronisław Markiewicz State Higher School of Technology and Economics in Jarosław, Poland

\section{AgNIESZKA ŚWIGOST}

Uniwersytet Jagielloński, Kraków, Polska

Jagiellonian University, Poland

\section{Przegląd problematyki wskaźników dotyczących kondycii ekonomicznej miast w Polsce}

\section{Review of the lssue of Indicators of the Economic Condition of Cities in Poland}

\begin{abstract}
Streszczenie: Studia porównawcze kondycji gospodarek miast niosą ze sobą wiele wyzwań, związanych m.in. z problemem dostępności adekwatnych danych i trafności wykorzystywanych wskaźników empirycznych i inferencyjnych. Niniej-szy artykuł ma na celu krytyczną analizę wskaźników stosowanych w porównawczych studiach poziomu rozwoju gospodarczego miast prowadzonych w Polsce. Dokonany przegląd ujawnia dużą różnorodność stosowanych przez autorów miar i występowanie kilku odmiennych perspektyw analitycznych. Zaobserwowana praktyka badawcza umożliwia postawienie tezy, że przyjęcie takiego a nie innego rozwiązania metodycznego jest z jednej strony determinowane dostępnością danych w statystyce publicznej, z drugiej zaś wynika z profesjonalnych przekonań autorów analizowanych badań co do cech składających się na obraz kondycji ekonomicznej miast oraz z różnej determinacji co do pozyskiwania alternatywnych miar w stosunku do tych zbieranych przez Główny Urząd Statystyczny. Do głównych wyzwań badawczych zaliczono słabą dostępność danych odnoszących się do wymiaru strukturalnego, poziomu innowacyjności i kondycji finansowej gospodarek miejskich. Wskazano działania, które mogłyby przyczynić się do rozwiązania zidentyfikowanych problemów. Należą do nich: zwiększenie współpracy i partnerstw publiczno-publicznych, wzmocnienie roli regionalnych obserwatoriów rozwoju regionalnego oraz przyjęcie metodologii opracowywania i zbierania danych, które trafnie odpowiadałyby na potrzeby diagnostyczne zmieniającej się kondycji gospodarek miejskich.
\end{abstract}

\footnotetext{
Abstract: Comparative studies of the condition of the economies of cities entail numerous challenges including the availability of adequate data and the accuracy of the empirical and inferential indicators. The purpose of the article is a critical analysis of indicators used in comparative studies of the level of economic development in Polish towns and cities. The review shows a large variety of measures used by the authors and the occurrence of several different analytical perspectives. On the one hand, based on the analyses, it seems that the choice of methods is determined by the availability of data in public statistics. On the other hand, it is related to the experience of authors regarding to the features that influence of the economic condition of cities. Moreover, this also involves the determination of the authors to obtain alternative measures compared to those collected by the Central Statistical Office. As the main research challenge, the authors identified poor availability of data related to the structural dimension, innovativeness and financial condition of urban
} 
economies. Furthermore, activities that could contribute to solving identified problems have been elaborated on. Those includes: increasing cooperation and the public-public partnerships, strengthening the role of the Regional Development Observatories and adopting a methods of data compilation and collection that would accurately respond to the diagnostic needs.

Słowa kluczowe: ekonomika miast; metoda wskaźnikowa; Polska; statystyka publiczna

Keywords: indicator analysis; Poland; public statistics; urban economics

Otrzymano: 7 stycznia 2019

Received: 7 January 2019

Zaakceptowano: 29 kwietnia 2019

Accepted: 29 April 2019

Sugerowana cytacja / Suggested citation:

Gwosdz, K., Micek, G., Sobala-Gwosdz, A., Świgost, A. (2019). Przegląd problematyki wskaźników dotyczących kondycji ekonomicznej miast w Polsce. Prace Komisji Geografii Przemysłu Polskiego Towarzystwa Geograficznego, 33(2), 59-80. doi: 10.24917/20801653.332.5

\section{WSTĘP}

W badaniach ekonomiczno-przestrzennych miasto jest często traktowane jak dynamiczny system gospodarczy, w którym - dzięki korzyściom aglomeracji w postaci wykształcenia się wyspecjalizowanego rynku pracy, dostępności infrastruktury oraz szybkiemu i łatwiejszemu przepływowi informacji i wiedzy pomiędzy przedsiębiorstwami - rozwijają się liczne podmioty gospodarcze różnej wielkości. Wejściem dla takiego systemu są zasoby gospodarki miasta (ludzkie, infrastrukturalne, kapitałowe itp.), zaś na wyjściu znajdują się produkty i usługi oferowane przez firmy, prowadzące do określonych wyników finansowych i innowacyjnych. Zarówno elementy wejścia, jak i wyjścia decydują o stopniu konkurencyjności (Domański, 1999; Klasik, 2001, 2008) danego miasta w stosunku do innych ośrodków i jego pozycji w przestrzennym podziale pracy.

Imperatyw prowadzenia przez jednostki terytorialne polityki rozwojowej rodzi coraz większe zapotrzebowanie na trafne wskaźniki statystyczne opisujące poszczególne wymiary rozwoju społeczno-gospodarczego, w tym kondycję ekonomiczną miasta (Dziemianowicz, 2005). J. Stiglitz, A. Sen i J-P. Fitoussi (2017: 7) podkreślają, że zapotrzebowanie to znacząco zwiększyło się w ostatnich dwóch dekadach, wobec faktu, że „wskaźniki syntetyczne są istotne dla projektowania i oceny polityk prospołecznych, a także oceny zmian funkcjonowania rynków gospodarczych".

Celem niniejszego artykułu jest krytyczny przegląd wskaźników stosowanych w porównawczych studiach poziomu rozwoju gospodarczego i kondycji ekonomicznej miast, prowadzonych w Polsce. Poddane przeglądowi badania, prowadzone zazwyczaj na zlecenie krajowych i regionalnych instytucji zarządzających, koncentrują się najczęściej na analizie poziomu rozwoju poszczególnych składowych gospodarki miasta, rzadziej na identyfikacji mechanizmów i czynników je kształtujących.

Tematyka artykułu dotyka szerszych problemów metodologicznych związanych z wykorzystywaniem wskaźników w naukach społecznych, w szczególności w geografii społeczno-ekonomicznej. Stosowanie metody wskaźnikowej zakłada przyjęcie podejścia realistycznego, w świetle którego nawet nieobserwowalne wprost konstrukty poznawcze mogą być opisywane przez obserwowalne wskaźniki empiryczne lub inferencyjne (zob. Nowak, 1965). Metodologiczne problemy pomiaru i konstrukcji wskaźników w naukach społecznych zostały szeroko przedstawione w pracach 
M. Bunge (1981, 2006), a ostatnio zwięźle podsumowane i usystematyzowane przez T. Czyż (2017).

Dalsza część artykułu składa się z trzech części. Pierwsza zawiera przegląd wskaźników (wraz z ich oceną) stosowanych w badaniach porównawczych kondycji ekonomicznej miast w Polsce. Następnie omówiono sposoby pomiaru funkcji gospodarczych miast i wynikającej z niego ich pozycji w przestrzennym podziale pracy. Ostatnia część przedstawia wyzwania, jakie stoją przed badaniami gospodarek miast i wnioski do dalszych badań.

\section{PRZEGLĄD WSKAŹNIKÓW STOSOWANYCH W BADANIACH PORÓWNAWCZYCH MIAST W POLSCE}

Analizy poziomu rozwoju gospodarczego miast w Polsce wykonywano w ostatniej dekadzie najczęściej na zlecenie samorządowych władz regionalnych lub innych gestorów, np. Ministerstwa Inwestycji i Rozwoju czy Europejskiego Banku Inwestycyjnego. Raporty takie zrealizowano dla województw: małopolskiego (Domański, Noworól, 2010), śląskiego (Sobala-Gwosdz, 2010), wielkopolskiego (Gadziński, Męczyński, 2011), podkarpackiego (Biernacki i in., 2012; Dziemianowicz, Charkiewicz, 2016) i pomorskiego (Guzik i in., 2015). Niektóre analizy prowadzono dla określonej grupy miast, np. miast małych i średnich (Konecka-Szydłowska, 2012; Korzeniak, 2014), byłych ośrodków wojewódzkich (Kurniewicz, Swianiewicz, 2016) lub monofunkcyjnych (Kubejko-Polańska, 2015). Badania o największym zasięgu przeprowadzono w Instytucie Rozwoju Miast (Dej, 2016) i Instytucie Geografii i Przestrzennego Zagospodarowania PAN (Śleszyński, 2016).

Liczba wskaźników diagnozujących kondycję ekonomiczną miasta była w analizowanych raportach różna. Największą ilością wskaźników uwzględnionych w analizie cechuje się analiza dotycząca województwa małopolskiego (21 zmiennych). Łącznie $\mathrm{w}$ analizowanych $\mathrm{w}$ niniejszym artykule 10 raportach lub publikacjach akademickich wykorzystano około 60 wskaźników, które na potrzeby niniejszego przeglądu pogrupowano w sześć dziedzin tematycznych: rynek pracy; przedsiębiorczość i obecność dynamicznych firm; struktura funkcjonalna; kondycja ekonomiczna firm, mieszkańców i samorządów; pozycja miasta w przestrzennym podziale pracy; aktywność innowacyjna oraz pozostałe wskaźniki, nieprzypisane do ww. kategorii (tabela 1).

Na poziomie miejskim nie wypracowano jednego, zagregowanego wskaźnika (analogicznego jak PKB na poziomie regionalnym czy krajowym), chociaż niektórzy autorzy (np. Jacobs, 1969) wskazują explicite na taką możliwość (przynajmniej w warstwie koncepcyjnej) ${ }^{1}$. Podejmując próbę pomiaru kondycji gospodarek miejskich (economic performance), najczęściej przyjmuje się strategię wyboru zestawu mierników i wskaźników, które intuicja badawcza przyjmuje jako trafne, bezpośrednie czy pośrednie odzwierciedlenie poszczególnych wymiarów składających się na pomiar stanu i dynamiki „gospodarki miasta”. Z uwagi na ograniczenia dostępnych danych, dość poważne w skali miast, wybór określonych wskaźników jest pewnym kompromisem pomiędzy ich

1 „Gdybyśmy musieli zmierzyć rozwój gospodarczy miasta [...] powinniśmy określić, jakie nowe działalności pojawiły się w jednostce czasu (the additions of new work to its older output) oraz jaki jest ich stosunek do tych, które już wcześniej tam występowały. Następnie, mówiąc o niskim lub wysokim wskaźniku rozwoju, porównywalibyśmy tempo dodawania nowych produktów i usług w różnych okresach czasu oraz między poszczególnymi miastami" (Jacobs, 1969). 
dostępnością a pożądaną merytoryczną poprawnością, zaś koncentracja na wybranych zjawiskach wpisujących się w rozwój gospodarczy wynika z celów poszczególnych analiz (m.in. podejmowana lub nie analiza zmian wskaźników w czasie).

Większa część autorów zmierza do konstrukcji wskaźnika syntetycznego, opartego na wskaźnikach cząstkowych lub subindeksach. Autorzy przyjmują przy tym najczęściej podejście addytywne, bez nadawania wag poszczególnym wskaźnikom. Wykorzystywaną powszechnie techniką jest wskaźnik sum standaryzowanych (tzw. Perkala). Cechuje się on zarówno względną prostotą konstrukcji, jak i małą utratą informacji podczas agregacji (zob. Chojnicki, Czyż, 1991; Churski, 2014). Zdaniem P. Churskiego (2012: 38) wskaźnik syntetyczny J. Perkala można traktować jako „nie w pełni satysfakcjonujący kompromis wynikający z wyboru najlepszej z testowanych metod statystycznych". Stosowane są także techniki dystansowe odległości od wzorca (Górecki i in., 2019) i metoda głównych składowych (Gadziński, Męczyński, 2011). Studia porównawcze wybranych metod porządkowania liniowego i ocena ich przydatności oraz poprawności ich stosowania były podejmowane w literaturze m.in. przez P. Churskiego (2012), P. Churskiego i J. Haukego (2012) oraz A. Bąka (2018). Dowiedziono w nich m.in. istnienia zależności osiągniętych wyników od rozkładu statystycznego zastosowanych wskaźników i metod agregacji.

\section{WSKAŹNIKI Z OBSZARU RYNKU PRACY}

Podstawą pomiaru kondycji gospodarek w analizach porównawczych są cechy odzwierciedlające sytuację na lokalnym rynku pracy. Wśród nich najczęstszymi wskaźnikami są: liczba pracujących odniesiona do ludności w wieku produkcyjnym, wskaźnik bezrobocia (stopa bezrobocia rejestrowanego jest dostępna w Polsce tylko do poziomu powiatów), struktura własnościowa (pracujący w sektorze publicznym i prywatnym), struktura pracujących według wieku oraz płci, a także wysokość wynagrodzeń.

Liczba pracujących w mieście znormalizowana przez liczbę mieszkańców w wieku produkcyjnym jest bardzo przydatnym (chociaż wstępnym i bez dalszych analiz niewystarczającym) zagregowanym wskaźnikiem kondycji gospodarki miasta. Z kolei zmiany liczby pracujących uważane są za jeden z wiodących wskaźników trendów gospodarczych (zob. m.in. The 2018 Silicon Valley Index..., 2019). Wskaźniki oparte na liczbie pracujących mają wartość w badaniach porównawczych o tyle, o ile obejmują one oszacowanie wszystkich pracujących w mieście. Istotną barierą porównawczych badań kondycji ekonomicznej miast w Polsce jest brak wiarygodnych i dokładnych danych o liczbie pracujących (według miejsca pracy). Udostępnione dane GUS nie uwzględniają zatrudnienia w podmiotach do dziewięciu pracujących (tzw. mikroprzedsiębiorstwach), dodatkowo zdezagregowane dane, np. na poziomie pojedynczych sekcji PKD, na poziomie miast i powiatów, są niedostępne ze względu na tajemnicę statystyczną (art. 10 i art. 38 ustawy z dnia 29 czerwca 1995 r. o statystyce publicznej).

Odsetek pracujących w mikropodmiotach, zwłaszcza w mniejszych miastach, może przekraczać nawet połowę pracujących²! Dlatego też konieczne jest doszacowanie tej wartości, w oparciu o badania reprezentatywne GUS (zob. np. Guzik i in., 2015) lub też szacunki z bazy danych REGON (Dej, 2016, i in.). Interpretując wartość wskaźnika

${ }^{2}$ W 2008 rok szacowany odsetek pracujących w mikroprzedsiębiorstwach w miastach województwa małopolskiego zawierał się między 19\% a 51\%, przy medianie wynoszącej 30\% (zob. Gwosdz i in. w: Domański i Noworól, 2010). 
liczby pracujących w odniesieniu do liczby ludności, zwłaszcza dla mniejszych miast w obszarach metropolitalnych, należy mieć na uwadze, że niska jego wartość nie musi oznaczać słabej kondycji lokalnej gospodarki, a jedynie fakt, że podstawą funkcjonowania takiego ośrodka jest funkcja mieszkaniowa. Wartościowe informacje niesie ze sobą dezagregacja liczby pracujących w podziale na płeć, a zwłaszcza na sektory własnościowe. Duży udział sektora publicznego (zwłaszcza w usługach), przy relatywnie niskiej liczbie pracujących ogółem per capita jest najczęściej dobrym desygnatem słabej kondycji gospodarczej miasta.

Nieco problematyczny jest stosowany w niemal wszystkich badaniach wskaźnik bezrobocia (liczba bezrobotnych w stosunku do ludności w wieku produkcyjnym) jako substytut niedostępnej na poziomie miast stopy bezrobocia rejestrowanego. Generalnie miary oparte na natężeniu bezrobocia sprawiają trudności interpretacyjne, gdyż mierzą (zwłaszcza w sytuacji niskiego bezrobocia) raczej cechy wyposażenia w kapitał ludzki czy poziom deprywacji w danej jednostce terytorialnej (Świgost, 2017) niż jej aktualną kondycję ekonomiczną. Dobrze odzwierciedla to tzw. paradoks Roubaix. W tym francuskim mieście położonym w konurbacji Nord-Pas de Calais, które przeszło głęboką restrukturyzację w latach 80. i 90., znajdowało się w drugiej połowie lat 2000. więcej pracujących niż ludności w wieku produkcyjnym, a równocześnie występowała tam bardzo wysoka stopa bezrobocia (Colomb, 2007). W tym sensie stopa bezrobocia może bardziej odzwierciedlać byłą, trudną kondycję gospodarczą miasta, która została utrwalona w cechach jego kapitału ludzkiego, niż wyrażać aktualny stan jego gospodarki. Sam zaś wskaźnik bezrobocia w badaniach porównawczych jest o tyle nieprecyzyjny, że nie pozwala na uwzględnienie różnej aktywności zawodowej wynikającej ze struktury lokalnego rynku pracy. Problem stanowi tu też zmiana definicji osoby bezrobotnej oraz rozwiązań związanych z ubezpieczeniem zdrowotnym czy programem $500+$. Prowadzi to do wzrostu lub spadku liczby bezrobotnych bez związku z kondycją ekonomiczną miasta. Niektórzy badacze wskazują na znacznie wyższą wartość diagnostyczną stopy aktywności zawodowej niż wskaźnika bezrobocia rejestrowanego (Beatty, Fothergill, Powell, 2007), niemniej jednak dostępność tego pierwszego tylko do lat spisu powszechnego ogranicza możliwości jego stosowania. Generalnie problemem miar opartych na liczbie pracujących jest to, że nie uwzględniają one roli szarej strefy oraz specyfiki miast, których gospodarki funkcjonują w cyklu „sezonowym” (np. miast turystycznych).

\section{WSKAŹNIKI PRZEDSIĘBIORCZOŚCI I OBECNOŚCI DYNAMICZNYCH FIRM}

Wskaźniki przedsiębiorczości uwzględniane są powszechnie w badaniach terytorialnego zróżnicowania poziomu rozwoju gospodarczego i konkurencyjności miast. Ich istotność wiąże się m.in. z coraz silniej docenianą rolą przedsiębiorców w teorii ekonomii (zob. Taleb, 2013; Thurik, Stam, Audretsch, 2013). Najczęściej wykorzystywanym wskaźnikiem jest poziom przedsiębiorczości, mierzony na podstawie liczby podmiotów gospodarczych, spółek prawa handlowego czy nowo zarejestrowanych podmiotów w rejestrze REGON, rzadziej wskaźniki tzw. demografii firm (zob. np. Gadziński, Męczyński, 2011; Dej, 2016).

Tak ujmowane zagregowane wskaźniki przedsiębiorczości mają jednak istotne deficyty. Zwłaszcza najczęściej stosowany wskaźnik przedsiębiorczości lokalnej (liczba zarejestrowanych podmiotów gospodarczych znormalizowana przez liczbę ludności) 
obarczony jest dwoma wadami, które mogą prowadzić do błędnych interpretacji. Nie uwzględnia on bowiem podstawowej różnicy między osobami, które zostały przedsiębiorcami „ze sposobności” (opportunity entrepreneurship), od tych, które zostały nimi „z konieczności” (necessity enterpreneurship) (zob. Kauffman Index of Startup Activity, 2017). Prosty wskaźnik przedsiębiorczości nadmiernie zawyża też pozycję miast, w których zarejestrowanych jest wiele mikroprzedsiębiorstw (np. w obszarach recepcji turystycznej) o często niskim potencjale wzrostu i w sektorach w małym stopniu opartych na wiedzy. Osobną sprawą jest aktualność urzędowych rejestrów (zob. np. dyskusja w: Śleszyński, 2017).

Od czasów głośnej pracy D.L. Bircha (1981), który zauważył, że młode, mikro lub małe firmy o dużej dynamice przychodów były głównym źródłem przyrostu miejsc pracy w gospodarce USA, stosowane są metody pomiaru aktywności przedsiębiorstw cechujące się dużym wzrostem przychodów i zatrudnienia. Nazywane są one za Birchem "gazelami biznesu”, a także high-growth firms (np. Eckhardt, Shane, 2011), rapid-growth firms (Barringer, Jones, Neubaum, 2005) oraz high-impact firms (Acs, Parsons, Tracy, 2008). Szczególnym zainteresowaniem badaczy cieszą się w ostatnich latach nowo zakładane przedsiębiorstwa w sektorach technologicznych. Z. Acs, W. Parsons i S. Tracy (2008) przeprowadzili badania, z których wynika, że firmy o dużej dynamice wzrostu i zatrudnienia, najczęściej stanowią między 2 a 3\% wszystkich firm na danym obszarze, występują w każdej grupie wielkościowej (według liczby zatrudnionych), działają w różnych rodzajach działalności gospodarczych, zarówno tych o niskim, jak i o wysokim poziomie technologicznym oraz niekoniecznie są to nowo zakładane firmy.

Ponieważ w Polsce nie są dostępne publicznie dane statystyczne na temat kształtowania się sytuacji ekonomicznej firm na poziomie niższym od województwa, próba identyfikacji dynamicznych małych i średnich firm zmusza do szukania innych źródeł informacji. Źródłem informacji wykorzystywanych w polskich badaniach był ranking przedsiębiorstw Gazele Biznesu opracowywany przez Coface Poland i publikowany w dzienniku ekonomicznym „Puls Biznesu”. Liczba ujmowanych w zestawieniu firm jest na tyle duża, że pozwala na pokazanie zróżnicowania tego zjawiska dla zagregowanych ciągów wieloletnich na poziomie miast. Przydatność gazel biznesu jako miernika poziomu rozwoju miast województwa pomorskiego testowali W. Biernacki i in. (2012), a jako wskaźnika działalności motorycznych w miastach województwa podkarpackiego - A. Sobala-Gwosdz (2016a, 2016b). Badano liczbę, poziom technologiczny (według klasyfikacji Eurostatu) i nasycenie danego obszaru (mierzone liczbą mieszkańców) gazelami biznesu. Wskaźniki te korelowano następnie z innymi miarami poziomu i dynamiki rozwoju gospodarczego, w szczególności zaś z poziomem przedsiębiorczości, bezrobociem i PKB (na poziomie subregionalnym). Na przykładzie miast konurbacji katowickiej dowiedziono m.in. silną współzależność między liczbą dynamicznych małych i średnich firm a stopą bezrobocia (Gwosdz, 2014).

Jako miernik kondycji miasta wykorzystywana jest również liczba działających w nim firm średnich i dużych. Jej przybliżeniem, dostępnym w statystyce publicznej, są zarejestrowane spółki prawa handlowego. W pracy pod redakcją M. Dej (2016) zrealizowano pracochłonne badania na podstawie danych zawartych w komercyjnej bazie Bisnode, mające na celu identyfikację $w$ miastach lokomotyw gospodarczych, zdefiniowanych jako „duże podmioty produkcyjne, które w istotny sposób oddziaływają na rozwój ekonomiczny otoczenia" (Wiedermann, Uliszak, Semczuk, 2016: 63). 


\section{WSKAŹNIKI STRUKTURY FUNKCJONALNEJ, DYWERSYFIKACJI I SPECJALIZACJI}

Jednym z najbardziej znanych dylematów debaty nad mechanizmami rozwojowymi w skali lokalnej jest kwestia zmian znaczenia korzyści aglomeracji typu MAR (Marshall, 1920; Arrow, 1962; Romer, 1990) i dywersyfikacji (Jacobs, 1969) dla rozwoju miast w zależności od ich etapu rozwoju (Kemeny, Storper, 2015; Schmidt, 2015). Proces lokowania się wzajemnie powiązanych ze sobą działalności we wzajemnej bliskości sprzyja większemu domknięciu efektów mnożnikowych. Zbyt silna specjalizacja jest jednak w dłuższej perspektywie rozwojowej niekorzystna, powoduje bowiem powstanie fenomenu „uwięzienia na dotychczasowej ścieżce rozwoju”, które może mieć charakter funkcjonalny, mentalny i polityczny (Grabher, 1993).

Ze względu na istotność empiryczną oraz silny związek teoretyczny z teoriami rozwoju miast, zwłaszcza z teorią J. Jacobs (1969), a ostatnio z koncepcją rezyliencji ${ }^{3}$ (zob. Drobniak, 2015; Masik, 2019), wskaźniki diagnozujące poziom specjalizacji i dywersyfikacji winny być uwzględniane w każdych badaniach porównawczych kondycji ekonomicznej miast. Zdaniem J. Jacobs (2017: 173) „stagnacji nie poddają się te miasta, które bezustannie wytwarzają nowe rodzaje aktywności gospodarczej”, stąd podstawowym wskaźnikiem mierzącym poziom rozwoju gospodarczego powinna być skala i dynamika powstawania w miastach nowych produktów i usług, a więc i działalności gospodarczej.

Badacze stosują najczęściej dwa podejścia do określania specjalizacji funkcjonalnej - bądź na podstawie struktury zatrudnienia według działalności gospodarczej, bądź też struktury branżowej zarejestrowanych w mieście podmiotów gospodarczych.

Najprostszymi wskaźnikami zróżnicowania struktury gospodarczej jest udział poszczególnych sektorów (przemysłowego, usługowego) w liczbie pracujących ogółem. Aktualnie ze względu na dostępność danych w oficjalnej statystyce jest to jedyny możliwy do wykorzystania w badaniach porównawczych miast w Polsce wskaźnik struktury oparty na liczbie pracujących. Niesie on w sobie pewną wartość diagnostyczną, jednak powinien on stanowić w normalnych warunkach co najwyżej wstępny etap diagnozy. Wartościowym wskaźnikiem jest zwłaszcza udział usług rynkowych czy udział działalności według zaawansowania technologicznego (np. według klasyfikacji Eurostat indicators on High-tech industry and Knowledge-intensive services; Eurostat, 2016). Możliwe to jest na zagregowanym poziomie w oparciu o dane zakupione przez GUS.

Zadowalający poziom agregacji danych (rekomendowany m.in. przez Eurostat, 2017) dla określenia stopnia specjalizacji nie powinien być niższy niż sekcje PKD. Podział taki umożliwia m.in. poprawną identyfikację specjalizacji funkcjonalnej w oparciu o metodę ilorazu lokalizacji lub stosowanie bardziej zaawansowanych wskaźników dywersyfikacji (np. wskaźnika Amemiya, Creamera czy Gibbsa-Martina). Jak pokazują doświadczenia autorów ostatnio zrealizowanych diagnoz kondycji miast, ten poziom agregacji ze względu na tajemnicę statystyczną jest niemożliwy do pozyskania, co wymaga stosowania najczęściej mało zadowalających protez, lub ograniczenia analiz tylko do dużych ośrodków, gdzie problem tajemnicy statystycznej jest mniejszy (zob. Dej, 2016).

Pewną wartość informacyjną niesie prosty wskaźnik monofunkcyjności (udział dominującego pracodawcy w liczbie pracujących ogółem) ${ }^{4}$. Stosowano go m.in.

\footnotetext{
${ }^{3}$ Rezyliencja ekonomiczna definiowana jest jako zdolność do rozwiązywania lokalnych i regionalnych problemów ekonomicznych w sposób zapewniający długookresowy sukces (Simme, Martin, 2009).

${ }^{4} \mathrm{~W}$ literaturze przyjmuje się 30\% udziału dominującej branży lub pracodawcy jako wskaźnik silnej monokultury gospodarczej (Coenen, Moodysson, Martin, 2015).
} 
w raportach pod redakcją M. Dej (2016) oraz B. Domańskiego i A. Noworóla (2010), a ostatnio przez J. Góreckiego i in. (2019). Liczbę zatrudnionych u głównego pracodawcy pozyskiwano z różnych źródeł, w tym przede wszystkim rocznych sprawozdań firm z działalności i rankingów największych firm. Badania porównawcze większej liczby miast tą metodą są jednak bardzo pracochłonne i uciążliwe, m.in. z uwagi na niekompletność aktualnych i wiarygodnych danych wtórnych. Obecnie sytuacja w tym względzie jest dużo trudniejsza niż jeszcze dekadę temu, m.in. ze względu na regres $w$ dostępnych bazach danych firm komercyjnych i procesy koncentracji przedsiębiorstw, które utrudniają identyfikację wielkości zatrudnienia w poszczególnych oddziałach/filiach.

Udostępniane w BDL GUS od 2009 roku dane dotyczące zarejestrowanych podmiotów gospodarczych na poziomie działów PKD dają podstawy do wnioskowania o stopniu specjalizacji gospodarczej, szczególnie metodą ilorazu lokalizacji. Podstawową słabością tych analiz jest to, że liczba podmiotów oddaje poziom rozwoju lokalnej gospodarki odniesiony właściwie do poziomu mikroprzedsiębiorstw, które obejmowały w Polsce w 2017 roku 95,8\% wszystkich zarejestrowanych podmiotów.

\section{WSKAŹNIKI KONDYCJI EKONOMICZNEJ SAMORZĄDÓW, FIRM I MIESZKAŃCÓW}

Konieczność uwzględnienia wysokości dochodów zlokalizowanych w mieście podmiotów (firm i mieszkańców) oraz samorządów lokalnych wynika ex definicione z samej koncepcji wzrostu gospodarczego. Łatwo dostępne w Polsce są jedynie wskaźniki dotyczące kondycji gospodarczej samorządów. Wykorzystywano m.in. takie miary, jak: udział dochodów własnych w dochodach ogółem, wielkość dochodów własnych budżetów gmin w przeliczeniu na jednego mieszkańca, nadwyżka operacyjna (bieżąca) w przeliczeniu na jednego mieszkańca, udział nadwyżki operacyjnej w dochodach ogółem, zadłużenie ogółem do dochodów ogółem (tabela 1). Na podkreślenie zasługuje wskaźnik nadwyżki operacyjnej (czyli różnica między dochodami bieżącymi a wydatkami bieżącymi), który zdaniem P. Swianiewicza (2007) jest najbardziej syntetyczną miarą sytuacji finansowej danej jednostki samorządu terytorialnego, swego rodzaju barometrem jej kondycji ${ }^{5}$.

Dochody firm i mieszkańców są dużo trudniej uchwytne w dostępnych danych statystycznych GUS. Niektórzy autorzy, opierając się na znanej wartości udziału PIT, szacowali średni dochód miesięczny przypadający na jednego mieszkańca (Biernacki i in., 2012, w oparciu o metodę Wojnickiej, 2008). Duże możliwości dają dane zbierane przez izby skarbowe, wykorzystane m.in. w analizach dotyczących gmin województwa małopolskiego (Binda, 2016) i miast konurbacji katowickiej (Kaleta i in., 2014).

\section{WSKAŹNIKI INNOWACYJNOŚCI}

Teorie rozwoju gospodarczego, w szczególności Schumpeterowska koncepcja „kreatywnej destrukcji" (Schumpeter, 2017) i teoria ekonomiki miast J. Jacobs (1969), kładą szczególny nacisk na zdolność działających w mieście firm do tworzenia nowych produktów i usług, a więc innowacji. Za P. Siłką (2010: 185) innowacyjność możemy

\footnotetext{
${ }^{5}$ Nieco bardziej krytyczną ocenę tego wskaźnika przedstawia M. Wiewióra (2008), wskazując, że „nie może dać jednak pełnej informacji o stanie gospodarki finansowej JST, bowiem nie uwzględnia ona dochodów/wydatków majątkowych oraz „strony przychodowo-rozchodowej” budżetu JST.”
} 
zdefiniować jako „zespół cech danego układu terytorialnego sprzyjający działalności innowacyjnej, podejmowanej przez podmioty gospodarcze w tym układzie". Innowacyjność można rozpatrywać na co najmniej dwóch płaszczyznach - cech środowiska społecznego i instytucjonalnego, które stymulują działalność innowacyjną, oraz mierzalnych efektów tej działalności, w postaci np. liczby i dynamiki innowacyjnych firm, wytwarzanych przez nie nowych produktów i usług czy zgłaszanych przez nie patentów. Na poziomie miast dostępność wskaźników o charakterze empirycznym lub inferencyjnym jest wysoce niezadowalająca, stąd w analizowanych badaniach autorzy zmuszeni byli przyjmować pewne przybliżenia, które łatwo mogą być przedmiotem krytyki. W. Biernacki i in. (2012) oraz R. Guzik i in. (2015) założyli, że desygnatem poziomu zróżnicowania potencjału innowacyjnego miast może być liczba i dynamika powstawania firm w tych sektorach gospodarki, które klasyfikowane są przez Europejskie Biuro Statystyki jako te o co najmniej średniowysokim poziomie techniki (w sektorze przemysłowym), oraz w usługach wiedzochłonnych i usługach wiedzochłonnych wysokiej techniki. Z kolei w raporcie dotyczącym miast podkarpackich (Dziemianowicz, Charkiewicz, 2016), w kontekście aktywności innowacyjnej miast, wykorzystano trzy wskaźniki oparte na projektach finansowanych ze środków UE: udział podmiotów z danych miast w zrealizowanych projektach innowacyjnych ogółem, liczba zrealizowanych projektów przez beneficjentów z ośrodków regionalnych oraz liczba zrealizowanych projektów naukowych współfinansowanych w ramach unijnych programów badawczo-naukowych przez beneficjentów z ośrodków regionalnych (tabela 1).

\section{PoZOSTAŁE WSKAŹNIKI KONDYCJI EKONOMICZNEJ MIAST}

Jako przybliżenie sytuacji ekonomicznej w danej jednostce wykorzystywano wskaźniki aktywności budowlanej (np. powierzchnia mieszkań oddanych do użytkowania na 100 mieszkańców). Od niedawna (co prawda tylko na poziomie powiatów, więc wskaźnik ten jest dostępny tylko dla niektórych miast) GUS udostępnia dane o cenach transakcyjnych nieruchomości. Dla wszystkich miast dane takie można pozyskać z płatnej bazy danych AMRON prowadzonych przez Związek Banków Polskich.

Dobrym wskaźnikiem nowoczesnego potencjału przemysłowego, stopnia jego integracji z gospodarką światową, a w efekcie poziomu konkurencyjności miasta jest wartość eksportu z miasta (Komornicki, 2006), który obliczany jest jako wartość obrotów towarowych w oparciu o dane z dokumentów SAD i deklaracji INTRASTAT. Interpretację tego wskaźnika, udostępnianego odpłatnie przez Krajową Administrację Skarbową ${ }^{6}$, utrudnia fakt, że obejmuje on wyłącznie obroty towarowe, a dane zbierane są metodą przedsiębiorstw.

Jednym z kluczowych wskaźników kondycji ekonomicznej miasta, jak i zarazem jego konkurencyjności i atrakcyjności inwestycyjnej, jest aktywność kapitału zagranicznego. W statystyce publicznej na poziomie miast dostępna jest liczba zarejestrowanych firm, a na poziomie powiatowym wybrane dane finansowe (dla wielu jednostek przestrzennych jednak niedostępne ze względu na tajemnicę statystyczną). Małopolska, jako jedyne województwo w Polsce (zob. Małopolskie Obserwatorium Rozwoju Regionalnego, 2019) prowadzi systematyczny monitoring napływu kapitału zagranicznego,

\footnotetext{
${ }^{6}$ Na podstawie zapisu § 2 rozporządzenia Ministra Finansów z dnia 12 lutego 2018 r. w sprawie trybu udostępniania danych INTRASTAT i EXTRASTAT oraz wysokości opłat za przetwarzanie tych danych.
} 


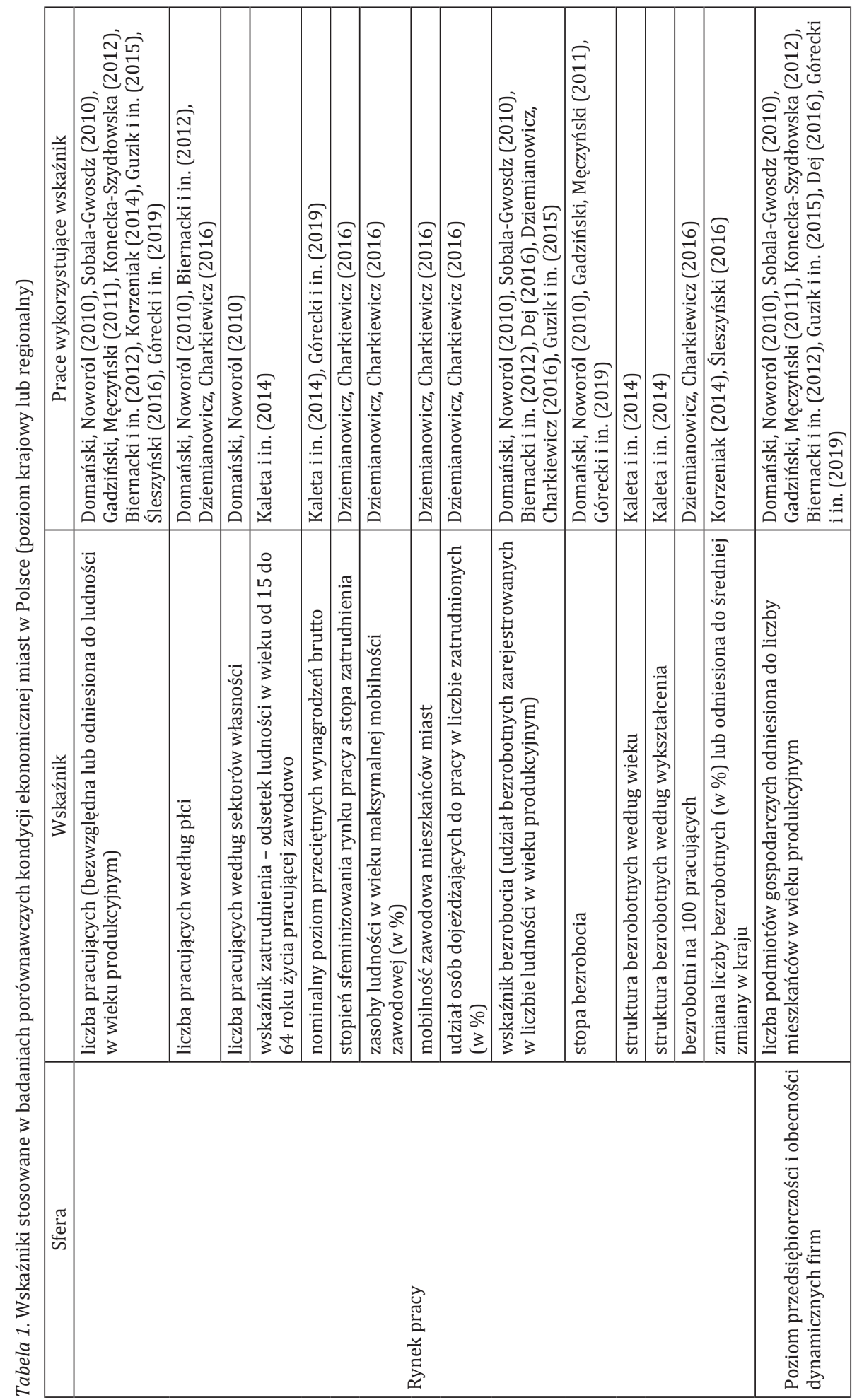




\begin{tabular}{|c|c|c|c|c|c|c|c|c|c|c|c|c|c|c|c|c|}
\hline 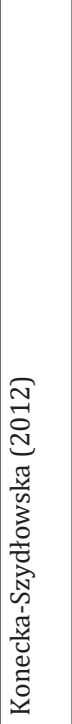 & 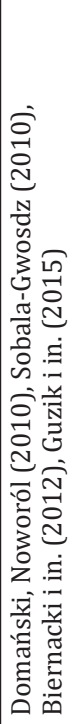 & \begin{tabular}{|l} 
\\
\\
\\
\\
\\
\\
0 \\
0 \\
0 \\
0 \\
0 \\
$\vdots$ \\
$\vdots$ \\
0 \\
0 \\
0 \\
0 \\
3 \\
0 \\
0 \\
$\frac{1}{\pi}$ \\
0 \\
0 \\
0
\end{tabular} & 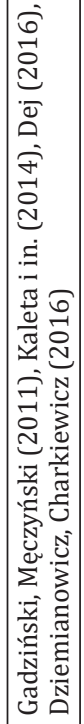 & 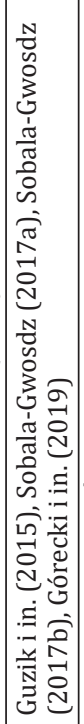 & 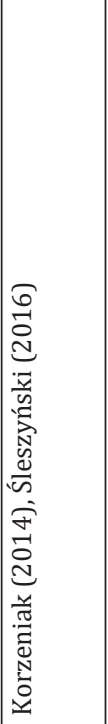 & 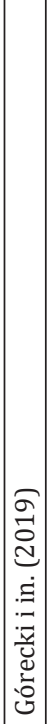 & 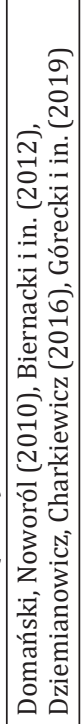 & 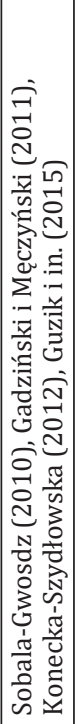 & 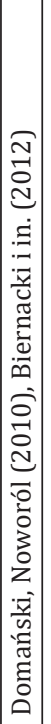 & 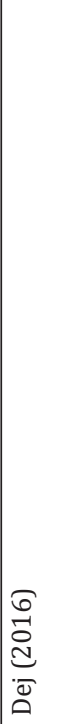 & 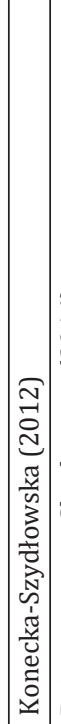 & 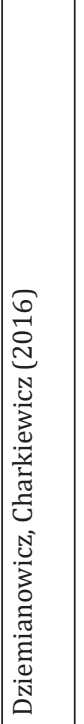 & 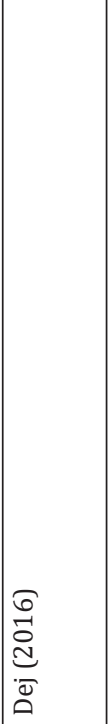 & 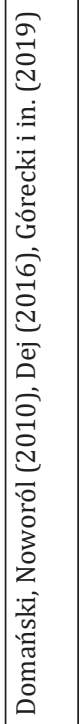 & 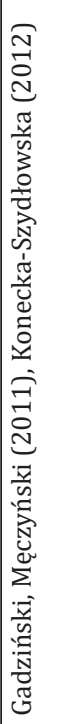 & 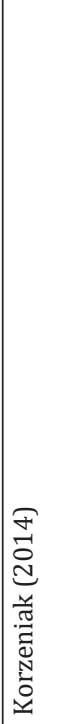 \\
\hline 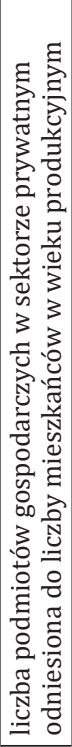 & 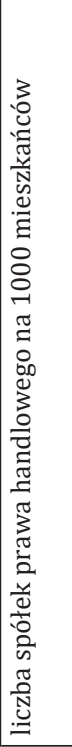 & 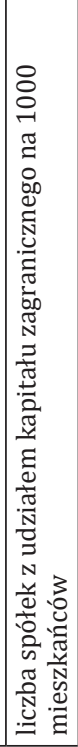 & 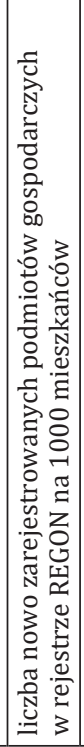 & 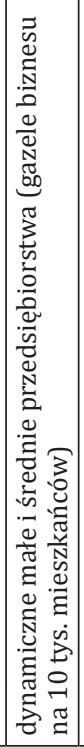 & 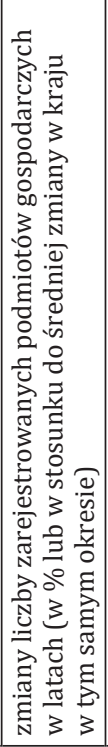 & 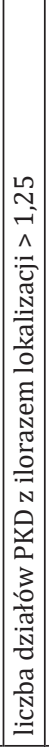 & 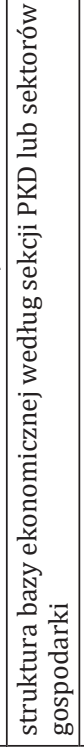 & 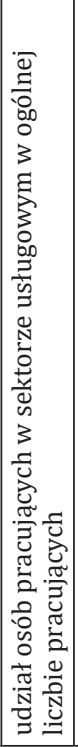 & 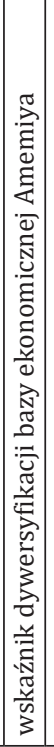 & 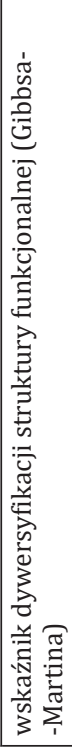 & 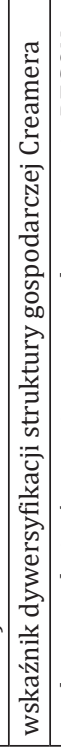 & 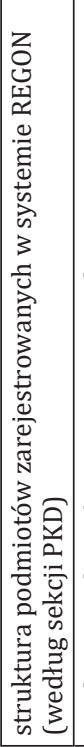 & 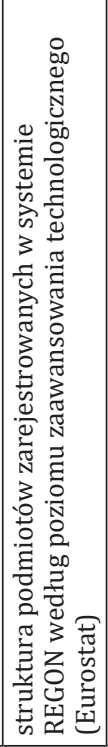 & 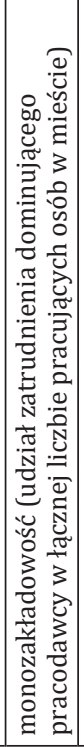 & 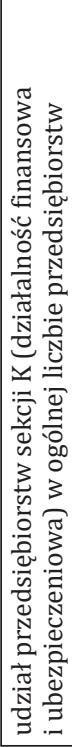 & 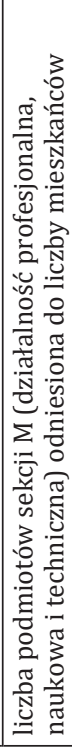 \\
\hline & & & 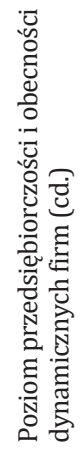 & & & & & & & & & 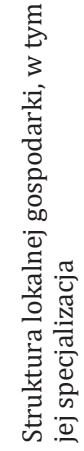 & & & & \\
\hline
\end{tabular}




\begin{tabular}{|c|c|c|c|c|c|c|c|c|c|c|c|c|c|}
\hline 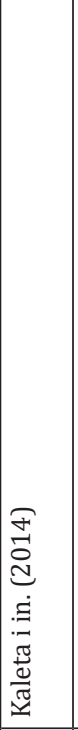 & 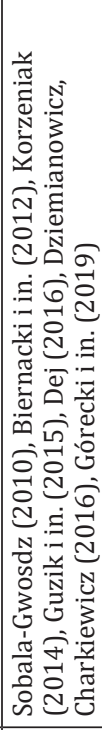 & 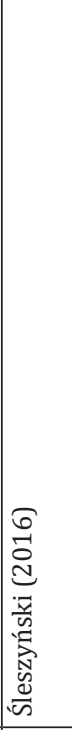 & 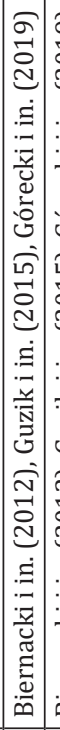 & 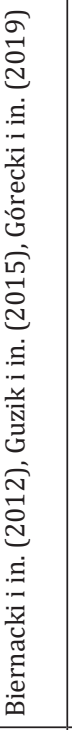 & 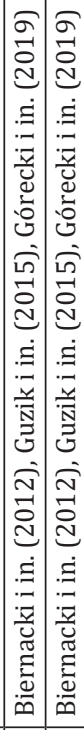 & 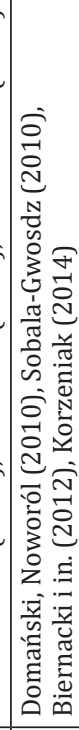 & 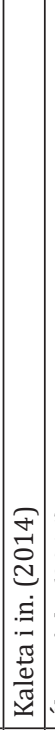 & 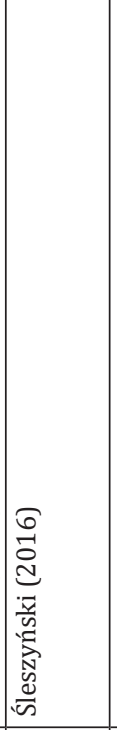 & 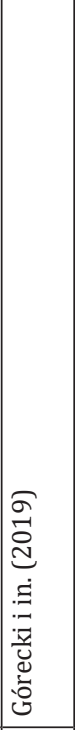 & 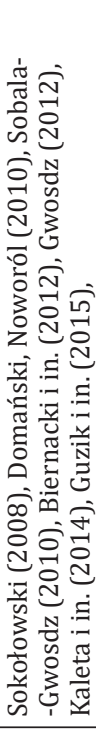 & 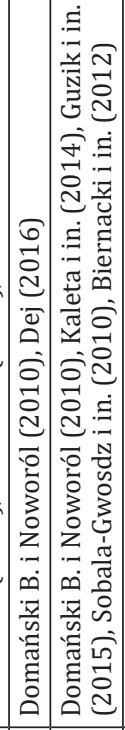 & 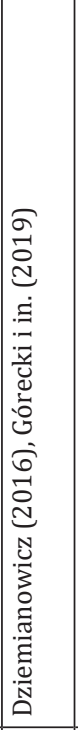 & 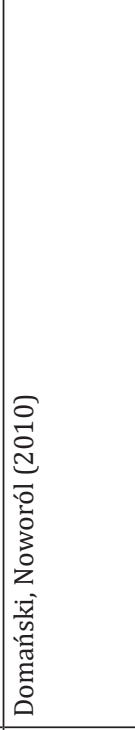 \\
\hline 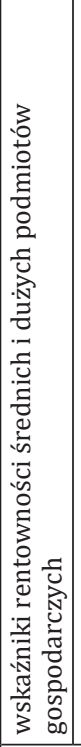 & 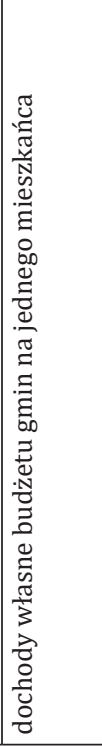 & 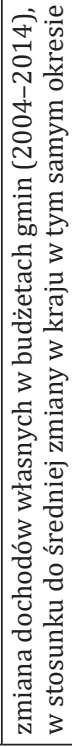 & 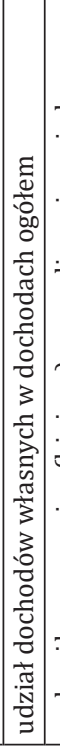 & 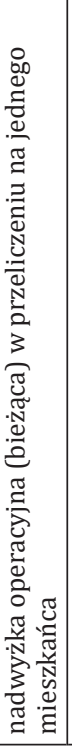 & 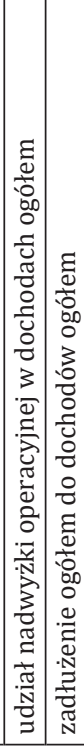 & 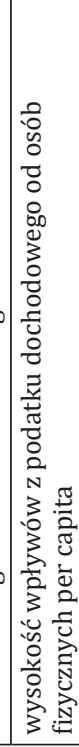 & 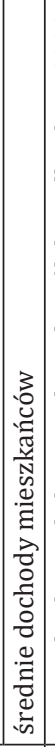 & 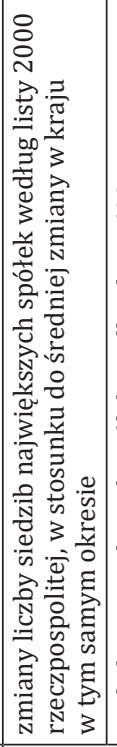 & 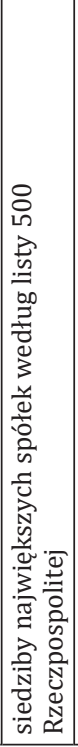 & 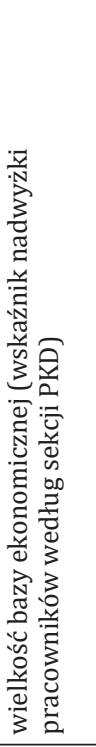 & 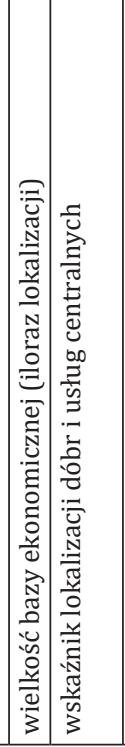 & 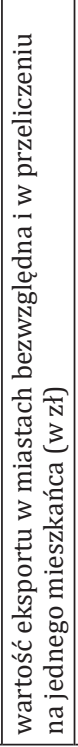 & 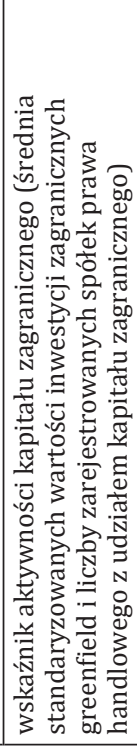 \\
\hline & & & 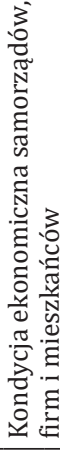 & & & & & & & & 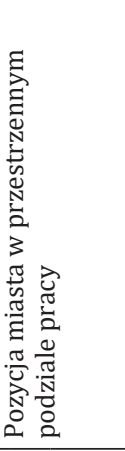 & & \\
\hline
\end{tabular}




\begin{tabular}{|c|c|c|c|c|c|c|c|c|c|c|}
\hline 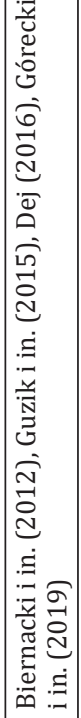 & 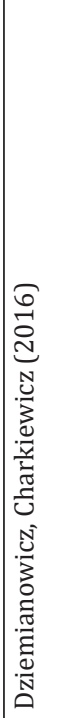 & 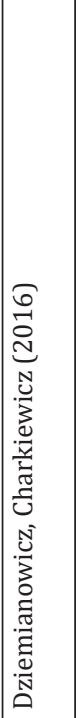 & 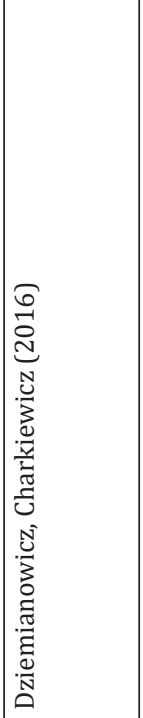 & 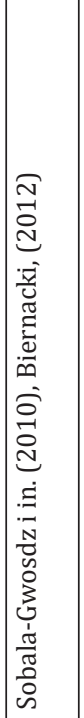 & 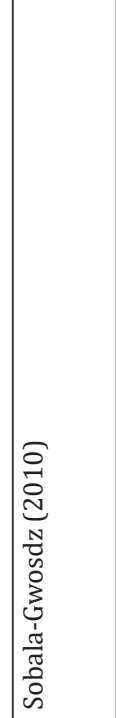 & 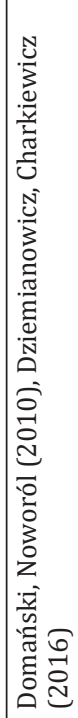 & 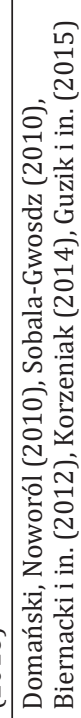 & 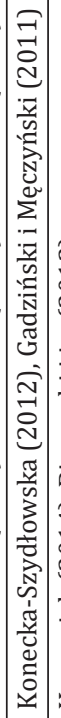 & 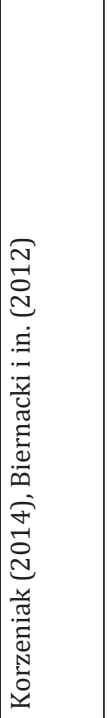 & \\
\hline 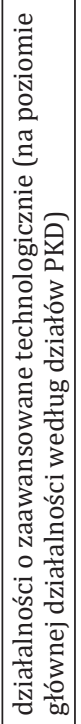 & 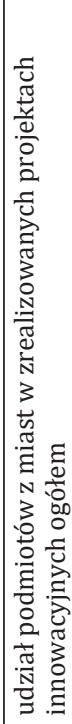 & 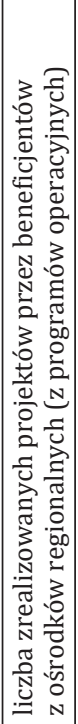 & 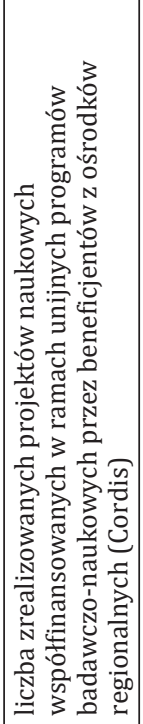 & 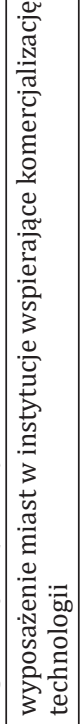 & 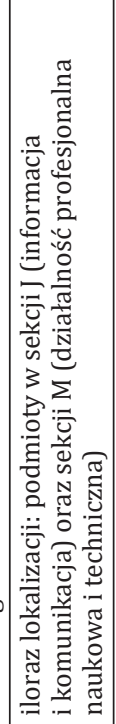 & 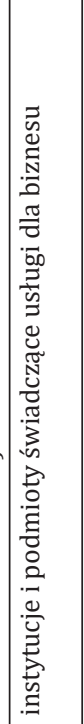 & 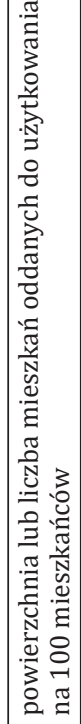 & 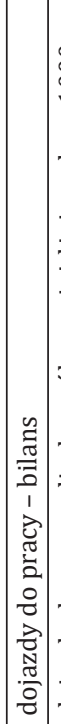 & 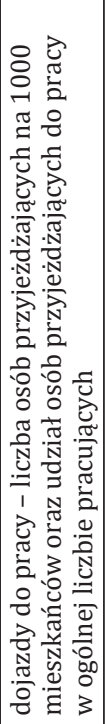 & \\
\hline
\end{tabular}

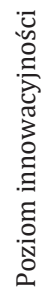

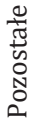


który umożliwia analizy na poziomie niższym niż wojewódzki w użytecznych przekrojach dziedzinowych (np. według typu inwestycji, działów PKD).

Zdaniem niektórych autorów „zmiany w podaży powierzchni handlowej, współczynniki pustostanów i wywoławczych stawek czynszów (czyli czynsz notowany dla nowych powierzchni) mogą pełnić funkcję wiodących wskaźników regionalnej działalności gospodarczej" (The 2018 Silicon Valley Index, 2018). W Polsce unikalne są badania obecności stref inwestycyjnych, zidentyfikowane głównie w oparciu o dane pozyskiwane bezpośrednio z miast (Dej, 2016). Dane o powierzchniach komercyjnych dostępne są tylko dla największych aglomeracji, w oparciu o raporty przygotowywane przez wyspecjalizowane firmy doradcze (np. JLL).

Wartościowym wskaźnikiem jest saldo dojazdów do pracy (w oparciu o dane udostępnione przez GUS dla 2006 i 2011 roku). Pozwalają one wnioskować m.in. o pozycji miasta w sieciach powiązań, co ma szczególne znaczenie w układach policentrycznych.

\section{IDENTYFIKACJA POZYCJI MIAST W PRZESTRZENNYM PODZIALE PRACY}

Badania porównawcze miast, oprócz analizy wskaźników kondycji gospodarczej omówionych w części drugiej niniejszego przeglądu, powinny zmierzać do ustalenia pozycji miast w sieciach i hierarchiach powiązań gospodarczych w skali ponadlokalnej (czyli ich miejsca w przestrzennym podziale pracy). Wyrazem tej pozycji jest wielkość i struktura ich bazy ekonomicznej, pełnione funkcje centralne, gateway ${ }^{7}$ oraz decyzyjno-kontrolne. Pierwsze dwa wymiary odwołują się do klasycznych koncepcji interpretujących mechanizmy rozwoju miast - bazy ekonomicznej i ośrodków centralnych Christallera. Z kolei porównawcza analiza sieciowa gospodarek miejskich ma swoje źródło w przekonaniu, że ośrodki miejskie łączą silne interakcje, które wyrażają się poprzez relacje między przedsiębiorstwami.

Koncepcja bazy ekonomicznej podkreśla wiodącą rolę działalności ukierunkowanych na ponadlokalne rynki zbytu. Powiązania branży eksportowych z lokalnym środowiskiem, m.in. poprzez zaopatrzenie w surowce, półprodukty i usługi oraz płace pracowników, powoduje mnożnikowy efekt, dzięki któremu rozwija się sektor endogeniczny. Sukces według tej koncepcji odnoszą przede wszystkim te miasta, które są zdolne do stworzenia silnej bazy ekonomicznej o wysokich lokalnych efektach mnożnikowych. Poziom rozwoju gospodarczego miasta w tej koncepcji odzwierciedlają wskaźniki bazy ekonomicznej, a zwłaszcza jej całkowita wielkość (mierzona najczęściej liczbą pracujących), struktura branżowa (rodzaj branż dominujących, rozwojowych i schyłkowych) i wskaźnik dywersyfikacji (Sokołowski, 2008; Gwosdz, Sobala-Gwosdz, 2012). Niestety, obecnie - jak już podkreślono - niedostępność odpowiednio zdezagregowanych danych o liczbie pracujących (wymagany przynajmniej poziom sekcji PKD) uniemożliwia w zasadzie analizę bazy ekonomicznej miast polskich w oparciu o klasyczne wskaźniki jej pomiaru, a tym samym znacznie utrudnia określenie pozycji miasta w przestrzennym podziale pracy, w szczególności w zakresie funkcji wyspecjalizowanych (obsługujących rynki zbytu poza obszarem miasta i jego zaplecza). Pozycję tę można jedynie aproksymować z danych dotyczących wartości eksportu.

Nadal istotną wartość dla określenia pozycji miasta ma teorii ośrodków centralnych W. Christallera (1933), która podkreśla znaczenie dla rozwoju danego miasta

\footnotetext{
${ }^{7}$ Według Ch. Zöpela (2011) funkcje gateway oznaczają dostęp do wiedzy oraz do ludzi.
} 
wielkości popytu na dobra i usługi zgłaszanego przez przedsiębiorstwa i ludzi zamieszkałych w nim samym i w obszarze jego zaplecza. Im rozleglejszy i gęściej zaludniony jest obszar obsługi, tym większe będzie miasto i tym więcej funkcji centralnych będzie w nim zlokalizowanych. Sukces miasta zależny w tym sensie od wielkości i zamożności obsługiwanego zaplecza (Dziemianowicz, Szlachta, Szmigiel-Rawska, 2011, określają to celnie „siła zaplecza siła bieguna”). Pozycję danego miasta w hierarchii ośrodków centralnych ujmuje się w postaci różnorodnych wskaźników skalarnych, pokazujących wyposażenie miasta w różnego typu działalności gospodarcze o charakterze centralnym oraz wektorowym, poprzez wyznaczenie zasięgu jego oddziaływania, np. poprzez określenie kierunków i wielkości dojazdów do pracy.

W świetle koncepcji sieciowych głównym mechanizmem rozwoju miast są przepływy społeczno-gospodarcze (Komornicki, 2003), które możemy podzielić na materialne (dóbr i usług, czasem nazywane fizycznymi - por. Domański, 1996, lub kapitału) i niematerialne (informacji lub wiedzy). Istnieją dwie możliwości wykorzystania analizy sieciowej do porównawczych studiów miejskich. Zazwyczaj stosowanym i klasycznym podejściem jest analiza wielkości i kierunków przepływów. Dużo rzadziej do studiów porównawczych wykorzystuje się metody analizy sieci społecznych (social network analysis). Głównym kryterium oceny znaczenia miasta jest jego pozycja w sieci, która może być określona poprzez stosowane w analizie sieci społecznych miary, m.in. centralność lub pośredniość (betweenness). 0 ile wartość pierwszego wskaźnika pozwala określić rangę ośrodka miejskiego, to druga miara mogłaby pozwolić określić wielkość defragmentacji sieci w razie upadku danego miasta.

Cennym dla analizy porównawczej dużych i średnich miast rodzajem interakcji są powiązania własnościowe, które można identyfikować za pomocą analizy właścicielskiej największych przedsiębiorstw (Śleszyński, 2007, 2016), na przykład tych notowanych na liście 2000 największych przedsiębiorstw dziennika „Rzeczpospolita”. Współcześnie dostępne bazy danych oparte na informacjach z Krajowego Rejestru Sądowego pozwalają na rozszerzenie takich analiz właścicielskich o dowolny rodzaj przedsiębiorstw działających w oparciu o prawo spółek handlowych, zarówno z uwagi na branże, jak i wielkość podmiotu. Poważnym ograniczeniem takich badań jest jednak ich niezwykle duża praco- i kosztochłonność.

$\mathrm{Na}$ ocenę pozycji gospodarki miejskiej w porównaniu z innymi ośrodkami mogą pozwolić również analizy wielkości i kierunków przepływów wiedzy (Micek, 2017), a zwłaszcza przepływy pracownicze, zwłaszcza kadry specjalistów i menedżerów. Z praktycznych względów takie - opierające się na bazach danych obejmujących pojedynczych pracowników (np. portale społecznościowe Linkedin, Goldenline) lub przedsiębiorstw - analizy nie mogą być jednak przeprowadzane dla wszystkich sektorów gospodarki.

Podstawowym dylematem studiów porównawczych miast opartych na analizie sieciowej jest problem odpowiedniości wykorzystywanych danych i wskaźników do opisu kierunków i natężenia przepływów. Pojawia się bowiem pytanie o to, co jest przedmiotem pomiaru, i w jakim stopniu wybrane wskaźniki opisują realne procesy (Czyż, 2017). Dodatkowo należy zauważyć, że pewna grupa tych powiązań ma charakter niewiążący i obejmuje interakcje przestrzenne, które nie konstytuują systemu, gdyż nie budują więzi między obiektami (Chojnicki, 1988). Poważny problem rodzi się w przypadku konieczności przeprowadzenia studiów dynamicznych, które wymagają dużej praco- i kosztochłonności. 


\section{WNIOSKI}

Przegląd wskaźników stosowanych w porównawczych studiach poziomu rozwoju gospodarczego miast, prowadzonych w Polsce, ujawnia dużą różnorodność stosowanych przez autorów miar i występowanie kilku odmiennych perspektyw analitycznych. Zaobserwowana praktyka skłania nas do postawienia tezy, że przyjęcie takiego, a nie innego rozwiązania metodycznego jest z jednej strony determinowane dostępnością danych w statystyce publicznej, z drugiej zaś wynika z profesjonalnych przekonań autorów co do cech składających się na obraz kondycji ekonomicznej miast oraz z różnej determinacji co do pozyskiwania alternatywnych miar w stosunku do tych zbieranych przez Główny Urząd Statystyczny.

Nie sposób się nie zgodzić z celną uwagą J. Stiglitza, A. Sena i J.-P. Fitoussiego (2017: 7), że „to, co mierzymy, wpływa na to, co robimy; a jeśli nasze pomiary są błędne, decyzje mogą być zniekształcone". Pomiar kondycji gospodarek miejskich i pełnionych przez miasta funkcji w przestrzennym podziale musi mieć charakter wielowymiarowy i potrzebna jest szeroka triangulacja metod i wskaźników, aby dana ekspertyza miała jakąkolwiek wartość praktyczną dla polityki lokalnej i regionalnej. Narzuca się pytanie, na ile obecnie dostępne publicznie i komercyjnie dane w Polsce to umożliwiają i jakie rekomendacje można zaproponować, aby zmienić ten stan rzeczy? Równocześnie należy mieć na uwadze dynamicznie zmieniającą się rzeczywistość gospodarczą, w szczególności rosnącą złożoność i współzależność gospodarek miast (Longhi, Musolesi, 2007; Domański, 2017, 2018), hybrydyzację wielu działalności gospodarczych (zob. Drobniak, 2017), postęp technologiczny, który zmienia dotychczasowe relacje na rynku pracy (m.in. w jego wymiarze przestrzennym) i fragmentację działalności w łańcuchach wartości dodanej, do niedawna związaną głównie z przemysłem, a obecnie w coraz większym stopniu z usługami, w szczególności z dynamicznie rosnącym w Polsce sektorem nowoczesnych usług biznesowych (Górecki, 2018). Dynamicznie zmieniająca się rzeczywistość, która koncepcyjnie ujmowana jest w teoriach nowej gospodarki (Audretsch, Thurik, 2001), wymaga opracowywania nowych wskaźników, które adekwatnie by ją opisywały.

Aktualnie możemy mówić o dwóch głównych problemach. Po pierwsze jest to niedostępność lub bardzo słaba dostępność danych odnoszących się do wymiaru strukturalnego gospodarek miejskich. Kluczowym problemem jest brak wiarygodnych i zdezagregowanych branżowo i terytorialnie danych o liczbie pracujących (według miejsca faktycznego pracy), a ponadto brak danych mierzących poziom innowacyjności gospodarek miejskich (np. danych patentowych) oraz niedostępność danych o kondycji finansowej lokalnej gospodarki (np. dostępność finansowania z różnych źródeł, aktywność kapitału krajowego i zagranicznego, dochody mieszkańców). Po drugie brakuje wskaźników, które trafnie odzwierciedlałyby zachodzące dynamiczne przemiany w gospodarce, w tym zmieniającą się pozycję miast w przestrzennym podziale pracy.

Można wskazać na następujące działania, które mogłyby przyczynić się do rozwiązania zidentyfikowanych problemów w dostępie do danych o kondycji ekonomicznej miast:

1. Zwiększenie współpracy i partnerstw publiczno-publicznych (pomiędzy poszczególnymi instytucjami państwowymi i samorządowymi a uczelniami) mających na celu identyfikację, analizę użyteczności i uwarunkowania publicznego udostępnienia zbiorów danych posiadanych przez poszczególne instytucje. Ze względu na 
zasób bardzo wartościowych informacji gospodarczych szczególnie ważny jest dostęp do danych gromadzonych przez Krajową Administrację Skarbową (istotnym postępem byłoby posiadanie chociażby danych o medianie dochodu mieszkańców i jej pochodnych).

2. Zwiększenie roli regionalnych obserwatoriów rozwoju regionalnego poprzez zapewnienie im odpowiedniego potencjału kadrowego i finansowego nieuzależnionego od cyklów finansowania ze środków UE, a także stymulowanie współpracy $\mathrm{z}$ wiodącymi instytucjami naukowymi w regionie. Jak pokazują doświadczenia województwa małopolskiego, aktywna rola obserwatoriów rozwoju prowadzi do wypracowania bardzo wartościowej wiedzy i wskaźników monitorujących poszczególne wymiary rozwoju gospodarczego, także na poziomie lokalnym.

3. Przyjęcie metodologii opracowywania i zbierania danych, które trafnie odpowiadałyby na potrzeby diagnostyczne zmieniającej się kondycji gospodarek miejskich. Wzorem mogą tu być rozwiązania przyjęte w krajach o wyższym stopniu zaawansowania gospodarki i organizacji statystyki publicznej. Przykładowo, w USA dostępne są dane dotyczące segmentacji lokalnych rynków pracy, w podziale na trzy poziomy (tiers): poziom 1 to zazwyczaj najlepiej płatne zawody łączące się z wysokimi kwalifikacjami, poziom 2 - zawody o średnich zarobkach i średnich umiejętnościach, zaś poziom 3 - stanowiska o niskich płacach oraz wymagające niskich kwalifikacji. Niezwykle przydatne byłyby zdezagregowane dane dotyczące obrotów towarowych w eksporcie (np. grup towarów o wysokiej, średniej lub niskiej wartości dodanej), co byłoby bardzo dobrym wskaźnikiem pozycji miasta w przestrzennym podziale pracy. Uzasadnione merytorycznie, a na dodatek nienaruszające restrykcyjnej tajemnicy statystycznej byłoby udostępnienie danych zdekomponowanych według zaawansowania technologicznego na poziomie podstawowych działalności gospodarczych zgodnie z klasyfikacją Eurostatu. Osobnym wyzwaniem jest kwestia, w jakich jednostkach terytorialnych prowadzić analizy, a zwłaszcza pytanie, na ile gospodarki miejskie badać w granicach administracyjnych miast, a na ile w zidentyfikowanych lokalnych rynkach pracy (zob. Gierańczyk, Ryczkowski, 2018).

\section{Literatura \\ References}

Acs, Z., Parsons, W., Tracy, S. (2008). High-impact firms: gazelles revisited. Small Business Research Summary, 328.

Arrow, K. (1962). The economic implications of learning by doing. Review of Economic Studies, 29, 155- 173.

Audretsch, D., Thurik, A. (2001). What's New about the New Economy? Sources of Growth in the Managed and Entrepreneurial Economies. Industrial and Corporate Change, 10(1), 267-315. doi: $10.1093 /$ icc/10.1.267

Bąk, A. (2018). Analiza porównawcza wybranych metod porządkowania liniowego. Prace Naukowe Uniwersytetu Ekonomicznego we Wrocławiu, 508, 19-28. doi: 10.15611/ pn.2018.508.02

Barringer, B.B., Jones, F.F., Neubaum, D.O. (2005). A quantitative content analysis of the characteristics of rapid-growth firms and their founders. Journal of Business Venturing, 20.

Beatty, C., Fothergill, S., Powell, R. (2007). Twenty years on: has the economy of the UK coalfields recovered? Environment and Planning A, 39(7), 1654-1675. 
Biernacki, W., Dej, M., Domański, B., Działek, J., Gwosdz, K., Guzik, R., Huculak, M., Janas, K., Jarczewski, W., Sobala-Gwosdz, A. (2012). Znaczenie projektów realizowanych $w$ ramach RPO WP dla rozwoju miast województwa podkarpackiego. Rzeszów: Urząd Marszałkowski Województwa Podkarpackiego.

Binda, A. (2016). Zbiory danych podatkowych z Izby Skarbowej jako źródło wiedzy o województwie. Kraków: Małopolskie Obserwatorium Rozwoju Regionalnego, Departament Polityki Regionalnej, Urząd Marszałkowski Województwa Małopolskiego.

Birch, D.L. (1981). Who creates jobs?. The Public Interest, 65, 3-14.

Bunge, M. (1981). Development indicators. Social Indicators Research, 9, 369-385.

Bunge, M. (2006). Chasing reality: strife over realism. Toronto: University of Toronto Press.

Chojnicki, Z. (1988). Koncepcja terytorialnego systemu społecznego. Przegląd Geograficzny, 60(4), 491-510.

Chojnicki, Z., Czyż, T. (1991). Zróżnicowanie przestrzenne poziomu i warunków życia ludności. Biuletyn Komitetu Przestrzennego Zagospodarowania Kraju Polskiej Akademii Nauk, 153.

Christaller, W. (1933). Die zentralen Orte in Süddeutschland: Eine ökonomischgeographische Untersuchung über die Gesetzmässigkeit der Verbreitung und Entckwiklung der Siedlungen mit städtischen Funktionen. Jena: Gustav Fischer Verlag.

Churski, P. (2012). Zróżnicowanie przestrzenne obszarów wzrostu i obszarów stagnacji gospodarczej w Polsce - wyzwania dla polskiej polityki spójności po 2013 r. Wyzwania polityki regionalnej. Rozprawy Naukowe Instytutu Geografii i Rozwoju Regionalnego Uniwersytetu Wrocławskiego, 27, 27-40.

Churski, P. (red.) (2014). The social and economic growth vs. the emergence of economic growth and stagnation areas. Poznań: Bogucki Wydawnictwo Naukowe.

Churski, P., Hauke, J. (2012). Statistical tools used in the identification of growth and stagnation areas - methods and empirical examples. W: 52-nd European Congress of Regional Science Association International, 4-th Central European Regional Science Conference, Regions and Motion. Breaking the Path. Abstracts. Bratysława, 74.

Coenen, L., Moodysson, J., Martin, H. (2015). Path Renewal in Old Industrial Regions: Possibilities and Limitations for Regional Innovation Policy. Regional Studies, 49(5), 850-865.

Colomb, C. (2007; 2019, 4 stycznia). Making connections: transforming people and places in Erope. Case study of Roubaix, Lille (France). URBED \& the Joseph Rowntree Foundation. Pozyskano z http://media.urbed.coop.ccc.cdn.faelix.net/sites/default/files/Case $\% 20$ Study $\% 20$ of $\% 20$ Roubaix\%20Lille.pdf

Czyż, T. (2017). Methodological problems in the design of indicators in social sciences with the focus on socio-economic geography. Studia Regionalia, 50, 49-61. doi: 10.12657/ studreg-50-03

Dej, M. (red.) (2016). Raport o stanie miast. Rozwój gospodarczy. Kraków: Instytut Rozwoju Miast.

Domański, R. (1996). Zasady geografii społeczno-ekonomicznej. Warszawa: Wydawnictwo Naukowe PWN.

Domański, R. (red.) (1999). The competitiveness of regions in the Polish and European Perspective. Warszawa: Wydawnictwo Naukowe PWN.

Domański, R. (2017). Złożoność przestrzeni ekonomicznej. Studia Krajowego Planu Zarządzania Kryzysowego, 178, 47-73.

Domański, R. (2018). Mechanizmy rozwoju przestrzeni ekonomicznej w kontekście debaty nad obszarami metropolitalnymi. Próba teoretycznej rekonstrukcji. Studia Krajowego Planu Zarządzania Kryzysowego, 186, 30-50.

Domański, B., Noworól, A. (red.) (2010). Małopolskie miasta - funkcje, potencjał i trendy rozwojowe. Kraków: Małopolskie Obserwatorium Rozwoju.

Drobniak, A. (2015). Koncepcja urban resilience: narzędzie strategicznej diagnozy i monitoringu miast. Ruch Prawniczy, Ekonomiczny i Socjologiczny, 77(1).

Drobniak, A. (2017). Nowe sektory gospodarki w rozwoju miasta - hybrydyzacja rozwoju. Katowice: Wydawnictwo Uniwersytetu Ekonomicznego w Katowicach.

Dziemianowicz, W. (2005). Ranking atrakcyjności inwestycyjnej miast Polski - refleksje po czterech edycjach badań. Prace i Studia Geograficzne, 35, 109-127.

Dziemianowicz, W., Charkiewicz, J. (red.) (2016). Miasta województwa podkarpackiego - perspektywy rozwoju. Szczecin: Wydawnictwo volumina pl Daniel Krzanowski. 
Dziemianowicz, W., Szlachta, J., Szmigiel-Rawska, K. (red.) (2011). Subregionalne bieguny wzrostu $w$ Polsce. Warszawa: Uniwersytet Warszawski.

Eckhardt, J.T., Shane, S.A. (2011). Industry changes in technology and complementary assets and the creation of high-growth firms. Journal of Business Venturing, 26.

Eurostat (2016). Eurostat indicators on High-tech industry and knowledge-intensive services (htec). Pozyskano z http://ec.europa.eu/eurostat/cache/metadata/DE/htec_esms.htm

Eurostat (2017). Methodological manual on city statistics. Luxembourg: Publications Office of the European Union.

Gadziński, J., Męczyński, M. (2011). Territorial diagnosis of competitiveness of urban areas in Poland. Poznań: Bogucki Wydawnictwo Naukowe.

Gierańczyk, W., Ryczkowski, M. (2018). Public Statistics Resources as a Source for Research in Geography of Industry. Prace Komisji Geografii Przemysłu Polskiego Towarzystwa Geograficznego, 32(4), 240-251. doi: 10.24917/20801653.324.15

Górecki, J. (red.). (2018). Sektor nowoczesnych usług biznesowych w Polsce. Warszawa: Związek Liderów Sektora Usług Biznesowych (ABSL).

Górecki, J., Gwosdz, K., Jarzębiński, M., Rotter-Jarzębińska, K., Fiedeń, Ł., Sobala-Gwosdz, A., Domańska, M., Świgost, A., Puchalski, Ł., Małochleb, K. (2019). Potencjał miast średnich w Polsce dla lokalizacji inwestycji BPO/SSC/IT/R\&D. Raport przygotowany przez Związek Liderów Sektora Usług Biznesowych (ABSL) dla Ministerstwa Inwestycji i Rozwoju w ramach projektu Strategii na rzecz Odpowiedzialnego Rozwoju (SOR) - Pakiet dla miast średnich.

Grabher, G. (1993). The Weakness of Strong Ties; the lock-in in regional development in the Ruhr Area. W: G. Grabher (red.). The embedded firm. On the socioeconomics of industrial networks. London-New York: Routlege, 255-277.

Guzik, R., Biernacki, W., Działek, J., Gwosdz, K., Kocaj, A., Kołoś, A., Panecka-Niepsuj, M., Sobala-Gwosdz, A., Sykała, Ł., Wiedermann, K. (2015). Analiza relacji funkcjonalno-przestrzennych między ośrodkami miejskimi i ich otoczeniem w województwie pomorskim. Gdańsk: Urząd Marszałkowski Województwa Pomorskiego.

Gwosdz, K. (2014). Pomiędzy starq a nowq ścieżkq rozwojowq̨: mechanizmy ewolucji struktury gospodarczej i przestrzennej regionu tradycyjnego przemysłu na przykładzie konurbacji katowickiej po 1989 roku. Kraków: Uniwersytet Jagielloński w Krakowie, Instytut Geografii i Gospodarki Przestrzennej.

Gwosdz, K., Sobala-Gwosdz, A. (2012). Struktura funkcjonalna i powiązania miast konurbacji katowickiej po dwóch dekadach restrukturyzacji. Przegląd Geograficzny, 84(4), 483-507.

Jacobs, J. (1969). The economy of cities. New York: Vintage Books.

Jacobs, J. (2017). Wielkie małe plany. Warszawa: Fundacja Centrum Architektury.

Kaleta, A., Zuzańska-Żyśko, E., Haberla, M., Wołczek, P., Kotlinski, A., Kaleta, M. (2014). Program Rozwoju Gospodarczego Metropolii „SILESIA” do 2025 r. Katowice: Metropolia Silesia.

Kauffman Index of Startup Activity (2017). Kansas City: Ewing Marion Kauffman Foundation.

Kemeny, T., Storper, M. (2015). Is Specialization Good for Regional Economic Development? Regional Studies, 49(6), 1003-1018.

Klasik, A. (2008). Aktywność przedsiębiorcza i konkurencyjność ekonomiczna miast w procesie restrukturyzacji aglomeracji miejskiej. Podstawy koncepcyjno-metodologiczne. Prace Naukowe / Akademia Ekonomiczna w Katowicach, 1.

Klasik, A. (red.) (2001). Konkurencyjność miast i regionów a przedsiębiorczość i przemiany strukturalne. Katowice: Akademia Ekonomiczna.

Komornicki, T. (2003). Przestrzenne zróżnicowanie międzynarodowych powiązań społeczno-gospodarczych w Polsce. Prace Geograficzne Instytutu Geografii i Przestrzennego Zagospodarowania Polskiej Akademii Nauk, 190.

Komornicki, T. (2006). Eksport w ujęciu regionalnym jako miernik rozwoju przemysłu. Prace Komisji Geografii Przemysłu Polskiego Towarzystwa Geograficznego, 8, 167-178.

Konecka-Szydłowska, B. (2012). Zróżnicowanie małych miast województwa wielkopolskiego ze względu na poziom rozwoju społeczno-gospodarczego. W: J. Słodczyk, E. Szafranek (red.). Studia miejskie, 8, 133-144.

Korzeniak, G. (red.). (2014). Małe i średnie miasta w policentrycznym rozwoju Polski. Kraków: Instytut Rozwoju Miast. 
Kubejko-Polańska, E. (2015). Przemiany potencjału i funkcji gospodarczych dawnych ośrodków monokultury przemysłowej Regionu Wschodniego w latach 1999-2009. W: A. Klasik (red.). Badania miejskie i regionalne. Potencjały rozwojowe oraz kierunki przemian w miastach i regionach. Katowice: Wydawnictwo Uniwersytetu Ekonomicznego w Katowicach, 88-115.

Kurniewicz, A., Swianiewicz, P. (2016). Ból fantomowy czy realna strata? Wpływ utraty statusu stolicy województwa na rozwój gospodarczy i miejsce w hierarchii systemu osadniczego. Prace i Studia Geograficzne, 61(2), 25-50.

Longhi, C., Musolesi, A. (2007). European cities in the process of economic integration: towards structural convergence. Ann Reg Sci, 41. doi: 10.1007/s00168-006-0104-4

Małopolskie Obserwatorium Rozwoju Regionalnego (2019, 7 stycznia). Pozyskano z https:// www.obserwatorium.malopolska.pl/

Marshall, A. (1920). Principles of Economics. London: MacMillan.

Masik, G. (2019). Sektory gospodarcze w badaniach odporności ekonomicznej regionów. Prace Komisji Geografii Przemysłu Polskiego Towarzystwa Geograficznego, 33(1), 117-129. doi: 10.24917/20801653.331.9.

Marshall, A. (1920). Principles of Economics. London: MacMillan.

Micek, G. (2017). Bliskość geograficzna przedsiębiorstw zaawansowanego przemysłu i usług a przepływy wiedzy. Kraków: Instytut Geografii i Gospodarki Przestrzennej Uniwersytetu Jagiellońskiego.

Nowak, S. (1965). Metody badań socjologicznych. Warszawa: Państwowe Wydawnictwo Naukowe.

Romer, P. (1990). Endogenous Technological Change. Journal of Political Economy, 98(5), 71-102.

Schmidt, S. (2015). Balancing the spatial localisation 'Tilt': Knowledge spillovers in processes of knowledge-intensive services. Geoforum, 65, 374-386.

Schumpeter, J. (2017). The Theory Of Economic Development. An Inquiry into Profits, Capital, Credit, Interest, and the Business Cycle. New York: Routledge.

Siłka, P. (2010). Przykład indeksu potencjału innowacyjnego dla wybranych miast Polski. Prace Komisji Geografii Przemysłu Polskiego Towarzystwa Geograficznego, 15, 185-196.

Simme, J., Martin, R. (2009). The Economic Resilience of Regions: Towards an Evolutionary Approach. Cambridge Journal of Regions, Economy and Society, 1-17.

Sobala-Gwosdz, A. (red.) (2010). Badanie trendów rozwojowych w województwie śląskim poprzez wyznaczenie ośrodków wzrostu i obszarów stagnacji. Bielsko-Biała: Strada Konsulting.

Sobala-Gwosdz, A. (2016a). Distribution and dynamics of development of small and medium-sized enterprises as a method of determining the growth centres. Example of podkarpackie region. Studia Regionalia, 47, 37-50.

Sobala-Gwosdz, A. (2016b). Gazele biznesu jako probierz poziomu rozwoju gospodarczego aktualnych i potencjalnych ośrodków wzrostu w województwie podkarpackim. Annales UMCS Sectio B, 71(2), 207-221.

Sokołowski, D. (2008). Baza ekonomiczna w większych miastach w Polsce w okresie transformacji systemowej. Przegląd Geograficzny, 80(2), 245-264.

Stiglitz, J., Sen, A., Fitoussi, J-P. (2017). Report by the Commission on the Measurement of Economic Performance and Social Progress.

Swianiewicz, P. (2007). Nadwyżka operacyjna. Wspólnota, 15.

Śleszyński, P. (2007). Gospodarcze funkcje kontrolne w przestrzeni Polski. Prace Geograficzne. Warszawa: Instytut Geografii i Przestrzennego Zagospodarowania Polskiej Akademii Nauk.

Śleszyński, P. (2016). Delimitacja miast średnich tracacych funkcje społeczno-gospodarcze. Warszawa: Polska Akademia Nauk, Instytut Geografii i Przestrzennego Zagospodarowania im. S. Leszczyckiego.

Śleszyński, P. (2017). Wyznaczenie i typologia miast średnich tracących funkcje społeczno-gospodarcze. Przegląd Geograficzny, 89(4), 565-593.

Świgost, A. (2017). Approaches towards social deprivation: Reviewing measurement methods. Bulletin of Geography. Socio-economic Series, 38, 131-141. doi: 10.1515/bog-2017-0039.

Taleb, N.N. (2013). Antykruchość. O rzeczach, którym służą wstrząsy. Warszawa: Kurhaus.

The 2018 Silicon Valley Index, People. Economy. Society. Place. Governance (2019, 7 stycznia). Silicon Valley Institute for Regional Studies.

Thurik, A.R., Stam, E., Audretsch, D.B. (2013). The rise of the entrepreneurial economy and the future of dynamic capitalism. Technovation, 33, 302-310. 
Wiedermann, K., Uliszak, R., Semczuk, M. (2016). Lokomotywy w rozwoju społeczno-gospodarczym miast. W: M. Dej (red.). Raport o stanie polskich miast. Rozwój gospodarczy. Kraków: Instytut Rozwoju Miast, 63-97.

Wiewióra, M. (2008). Wpływ nadwyżki operacyjnej budżetu na kondycję finansową jednostki samorządu terytorialnego. Studia i Prace Kolegium Zarządzania i Finansów, Szkoła Główna Handlowa, 86, 143-152.

Wojnicka, E. (2008). Dochody osób i podmiotów prawnych na poziomie lokalnym w województwie podkarpackim i lubelskim. Barometr Regionalny, 2(12), 11-23.

Zöpel, Ch. (2011). Zagłębie Ruhry i Górny Śląsk w sieci metropolii europejskich. Aglomeracje przemysłowe jako metropolitalne obszary miejskie. Gliwice: Dom Współpracy Polsko-Niemieckiej.

Krzysztof Gwosdz, dr hab., prof. UJ, Uniwersytet Jagielloński, Wydział Geografii i Geologii, Instytut Geografii i Gospodarki Przestrzennej, Zakład Rozwoju Regionalnego. Zajmuje się problemami rozwoju lokalnego i regionalnego, bezpośrednimi inwestycjami zagranicznymi, społecznymi i ekonomicznymi problemami miast oraz restrukturyzacją i rewitalizacją miast oraz regionów tradycyjnego przemysłu.

Krzysztof Gwosdz, PhD, associate professor, Jagiellonian University in Krakow, Faculty of Geography and Geology, Institute of Geography and Spatial Management, Department of Regional Development. His research interests are focused on issues of local and regional development, foreign direct investment, social and economic problems of urban areas and restructuring and regeneration of old industrial towns and regions.

ORCID: 0000-0002-6670-2422

\title{
Adres/address:
}

\author{
Uniwersytet Jagielloński \\ Wydział Geografii i Geologii \\ Instytut Geografii i Gospodarki Przestrzennej \\ ul. Gronostajowa 7, 30-387 Kraków, Polska \\ e-mail: krzysztof.gwosdz@uj.edu.pl
}

Grzegorz Micek, dr hab., prof. UJ, Uniwersytet Jagielloński, Wydział Geografii i Geologii, Instytut Geografii i Gospodarki Przestrzennej, Zakład Rozwoju Regionalnego. W swoich badaniach koncentruje się na problematyce rozwoju zaawansowanych działalności gospodarczych w kontekście przestrzennym. Podejmuje analizy wpływu dużych inwestycji oraz wybranych sektorów gospodarki na rozwój lokalny i regionalny. Interesuje się szeroko pojętą geografią ekonomiczną (zwłaszcza obejmującą sektor usług). Stosuje zarówno ilościowe, jak i jakościowe metody badań.

Grzegorz Micek, PhD, associate professor, Jagiellonian University in Krakow, Faculty of Geography and Geology, Institute of Geography and Spatial Management, Department of Regional Development. In his research, the author focuses on the development of advanced economic activities in a spatial context. He undertakes analyses of the impact of large investments and selected sectors of the economy on local and regional development. The author is interested in the broadly understood economic geography (especially in services sector). He applies both quantitative and qualitative research methods.

ORCID: 0000-0001-9552-9326

\section{Adres/address:}

\author{
Uniwersytet Jagielloński \\ Wydział Geografii i Geologii \\ Instytut Geografii i Gospodarki Przestrzennej \\ ul. Gronostajowa 7, 30-387 Kraków, Polska \\ e-mail: grzegorz.micek@uj.edu.pl
}

Agnieszka Sobala-Gwosdz, dr, Państwowa Wyższa Szkoła Techniczno-Ekonomiczna w Jarosławiu, Instytut Inżynierii Technicznej. Bada zagadnienia rozwoju lokalnego i regionalnego. Prowadzi badania głównie w regionach peryferyjnych i nadgranicznych, szczególnie w południowo-wschodniej Polsce. Koncentruje się w szczególności na teorii biegunów wzrostu, bezpośrednich inwestycjach zagranicznych i rewitalizacji miast. 
Agnieszka Sobala-Gwosdz, PhD, The Bronisław Markiewicz State Higher School of Technology and Economics in Jarosław, Institute of Technical Engineering. Her research interests cover issues of local and regional development. She has undertaken research mainly in peripheral and frontier regions, especially in South-Eastern Poland. She focuses particularly on the growth poles theory, foreign direct investment and urban regeneration.

ORCID: 0000-0001-5603-4910

\section{Adres/address:}

Państwowa Wyższa Szkoła Techniczno-Ekonomiczna w Jarosławiu Instytut Inżynierii Technicznej

ul. Czarnieckiego 16, 37-500 Jarosław, Polska

e-mail: asobala@poczta.fm

Agnieszka Świgost, mgr, Uniwersytet Jagielloński, Wydział Geografii i Geologii, Instytut Geografii i Gospodarki Przestrzennej, Zakład Rozwoju Regionalnego. W swoich badaniach koncentruje się na zagadnieniach związanych z rozwojem regionalnym i lokalnym, ze szczególnym uwzględnieniem roli kobiet, geografią miast, partycypacją społeczną (inicjatywy lokalne, innowacje, ruchy miejskie), społecznym wymiarem rewitalizacji oraz transportem rowerowym.

Agnieszka Świgost, MSc, Jagiellonian University in Krakow, Faculty of Geography and Geology, Institute of Geography and Spatial Management, Department of Regional Development, Her research interests: regional and local development with particular emphasis on the role of women, urban geography, social participation (local initiatives, innovations), the social dimension of revitalisation, green areas in the city, bicycle transport.

ORCID: 0000-0002-3229-0271

\section{Adres/address:}

Uniwersytet Jagielloński

Wydział Geografii i Geologii

Instytut Geografii i Gospodarki Przestrzennej

ul. Gronostajowa 7, 30-387 Kraków, Polska

e-mail: agnieszka.swigost@doctoral.uj.edu.pl 